\title{
Analyzing the Effect of the COVID-19 on the Global Economy: A Case Study of Its Influence on Africa's FDI and Foreign Exchange Inflows
}

\author{
Isaac Adjei Tetteh, Jin Gao \\ School of Economics and Management, Shanghai Maritime University, Shanghai, China \\ Email: gudnews84@gmail.com
}

How to cite this paper: Tetteh, I. A., \& Gao, J. (2020). Analyzing the Effect of the COVID-19 on the Global Economy: A Case Study of Its Influence on Africa's FDI and Foreign Exchange Inflows. Open Journal of Business and Management, 8, 2396-2401. https://doi.org/10.4236/ojbm.2020.86147

Received: October 4, 2020

Accepted: November 1, 2020

Published: November 4, 2020

Copyright $\odot 2020$ by author(s) and Scientific Research Publishing Inc. This work is licensed under the Creative Commons Attribution International License (CC BY 4.0).

http://creativecommons.org/licenses/by/4.0/

\begin{abstract}
The global economy has taken a major hit due to the grave effect of the spread of COVID-19. Developed countries are struggling to sustain their economies and this gives an indication of the current state of developing and underdeveloped nations. The closure of businesses and the laying off of some workers, coupled with the closure of some international air and sea ports indicates the stagnation of global economic growth and process with a forecasted massive recession. The local governments of various countries have collectively inputted strategic efforts to supplement the situation with diverse financial relief funds and fiscal assistance policies. The GDP of the global economy is predicted to shrink by $5.2 \%$ according to the minimum economic forecast predictions (World Bank, 2020). The severity of the pandemic will undoubtedly leave a negative and uninspiring blueprint on the face of the global economy. The pandemic like a binocular has exposed the multifaceted cracks in the various economy sectors and their unpreparedness for global storms such as this. Foreign Direct Investment and foreign exchange inflows into the continent of Africa have been stable on average over the years; however, the current state of the global economy predicts a sharp fall which will not easily recover until there has been a full recovery. This gives a baseline forecast of the adverse effect of the pandemic on the African soil as well as other developing and underdeveloped countries and regions globally. Therefore, various governments within the continent must develop and implement breakwater policies such as intra-regional integrations as well as strong international relations that will help hedge against and cushion the effect of another global storm. This paper seeks to analyze the effect of the pandemic on the global economy, a case study of its influence on Africa's FDI and foreign exchange inflows.
\end{abstract}




\section{Keywords}

Global Economy, Pandemic, Recession, Africa, Foreign Direct Investment, Foreign Exchange

\section{Introduction}

The outbreak of the corona virus is the third pandemic to hit the globe with their rippling effects on education, the financial and industrial sectors, the health and the aviation sectors among many others. The COVID 19 is the follow up of the SARS of 2002-2003 and the MERS of 2012 (Yang et al., 2020) and its effect on the continent of Africa has been intense just like the rest of the globe. Africa over the years has had to rest on the shoulders of giant investors from developed countries to undertake many developmental projects within its various economy sectors. However, the resurgence of the coronavirus in the latter end of 2019 after its last appearance in 2012, poses a great economic, industrial and technological disadvantage to the continent as a whole. This is due to the varying forms of foreign direct investments and foreign exchange that the continent receives from other foreign countries, firms and institutions.

According to UNCTAD's World Investment Report (UNCTAD, 2020), although the African continent had seen a significant increase in FDI inflows of 17.9\% between 2017 and 2018, it however experienced a 9.1\% decrease between 2018 and 2019 which saw the real figures fall from $\$ 49.5$ billion dollars in 2018 to $\$ 45$ billion dollars in 2019. This shows that FDI inflows into the continent had been adversely affected even before the pandemic, and with a forecast of 5.2\% global economic shrinkage, all things being equal, the FDI inflows into Africa will most likely decline by a further $5.2 \%$.

In as much as Africa found a way to diverge from the implications of the declined state of global FDI in 2018 by enjoying an increase in FDI inflows, its largest region which is Sub-Saharan Africa experienced a devastating percentage decrease of $90.76 \%$ between 2018 and 2019 with actual figures of $\$ 30.839$ billion and $\$ 2.848$ billion respectively (World Bank, 2020). Thus, the year 2020 was supposed to be a year for the amendment of certain policies within the region and the continent as a whole and more so the development of the various sectors of the economy for the continuous and increased attraction of FDI. However, the current state of the global economy and its associated limitations to production and consumption denotes that Africa as a whole will be hugely affected and as such many projects and economic undertakings within the continent which are being sponsored by foreign investors from developed countries will be on hold until there has been at least a half way recovery from this global pandemic and its setbacks on the economic strength of various foreign governments, firms and institutions. 


\section{Literature Review}

Africa has mostly relied on the unchanged and consistent stock of investment from France which has been the continent's major benefactor along with the Netherlands, America and China. The latter country which is China has been a major investor into the continent in terms of finance and other resources. Its FDI has not been centered in a particular region but literary across the whole continent. The beginning of the pandemic from Wuhan in China which culminated into a massive lockdown of the people in China as well as the temporary closure of International ports meant that most of the economic activities and exchanges between most African countries and China had to be halted. FDI before the pandemic had already taken a down turn between the past two years; 9.1\% decrease between 2018 and 2019. Figure 1 shows that FDI inflows significantly increased with a $17.9 \%$ margin from 2017 to 2018 . Nonetheless, it decreased by $9.1 \%$ between from 2018 to 2019 .

Africa on the other hand had also experienced a decline in outflows of FDI with a percentage decrease of $35 \%$ which accounted for $\$ 5.3$ billion dollars (UNCTAD, 2020). According to the World Investment Report (UNCTAD, 2020), the continent of Africa has been predicted to experience a $25 \%$ to $40 \%$ contraction of FDI flows on the projected growth of the continent's GDP. The United States of America whom the continent of Africa also greatly benefits from has also been dealt a great blow from the pandemic as it is currently the epicenter of the pandemic. According to the Worldometers (2020), the current infection rate in the United States of America currently stands at 8,288,278 with 223,644 deaths and 5,395,401 and recoveries. This indicates the severity of the virus in America and how various giant industries are being affected. Sub Saharan Africa which almost represents the whole of Africa has been a great beneficiary of the United States of America especially when it comes to the importation of agricultural products which have soared within the past decade of more than $200 \%$, having grossed a record high of $\$ 2.9$ billion dollars in 2011 (FAS, 2013). Nigeria alone in 2014 accounted for $\$ 847$ million dollars (14\%) of the total agro exports from the U.S into the region specifically with wheat importation, as the country is the third largest wheat importer from America (FAS, 2015). The African continent as a whole has relied on the support of foreign countries to balance food security within its borders with a staggering figure of $\$ 48.5$ billion dollar worth of agro imports in 2014 (FAS, 2015). Nonetheless, this has not been able to make the continent overcome the challenge of one out of four children suffering from hunger or malnutrition, meaning that the continent has a quarter of its population suffering from malnutrition. This then gives an indication of the severity of the pandemic on the African continent. With countries struggling to survive by making sure that there is enough food supplies and other daily consumable goods available to their citizens who until recently had been on lockdown for months means that the original quantities which were usually sent into the African market would have decreased by more than $50 \%$. 


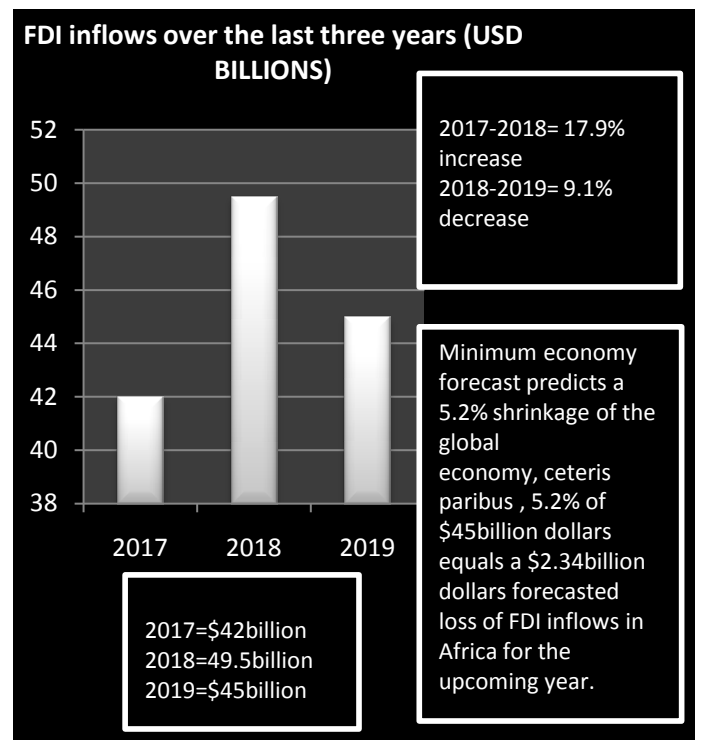

Figure 1. FDI inflows into Afirca between 2017 and 2019.

Computations by author, data from UNCTAD (2020).

Although examples of similar crises have seen foreign investors coming to the aid of their international affiliates (Alfaro \& Chen, 2012; Desai et al., 2008), the nature of this current pandemic makes it less likely for that to happen very soon. Also, the severity of the lockdowns moved almost all countries across the globe to secure relief funds and stimulus bills for individuals and institutions which have been greatly affected by the pandemic. This also means that the flow of foreign financial aids and loans will not be easily available to the continent as every country is struggling to care for their very own. The case of the United States of America is very critical as the nature of the pandemic and its damning effect on the nation induced the president into signing a $\$ 2$ trillion dollar stimulus bill to support greatly affected citizens and institutions. America's stimulus bill is unprecedented and this means that the country will look to rebuild and recover their economy before stretching out their hands to support other countries. The pandemic at its beginning was responsible for the closure of many industries and production companies and this led to the laying off of some workers as well as others having to temporarily reduce workers' salaries. Some companies have had to reduce their employee numbers in order to cut down production cost and remain in operation whilst others who were hardly hit by this pandemic have had to shut down completely as some of them were making huge losses (Celik et al., 2020) whereas others closed down foreign operations (Borga et al., 2020). This prompted respective governments to employ ways and means to sustain and revive some of these companies as well as supporting those individuals whose employments have been affected by the pandemic through furlough programs. All of these form part of the exogenous implications or effect of the pandemic on the African soil especially from the institutional or governmental level. Other exogenous effect of the pandemic on the African continent is the issue of 
tourism. Africa boasts of many world tourists sites, forest reserves and national parks along with other historical sites which are symbols of the diverse cultural backgrounds in the continent and those that even reflect the times of slavery. These historical sites and scenes in Africa have over the years been one of the major targets of foreign investors, especially for the setting up of hotels for visitors. These places are also a great source of foreign exchange into the continent and as such the current pandemic which has lately spread within the whole continent implies that foreign investments as well as foreign exchange gotten through tourism will drastically reduce, at least until the pandemic is over. An attributed factor is the limitations to international travels between nations and regions in order to manage or control the spread of the pandemic. More so, other related areas of financial inflows into the continent are that of remittances from local nationals living abroad. The current state of the global economy which has resulted in the laying off of some workers indicate that some of the African diaspora who are currently living abroad and have had their employment status affected implies that those people will no longer be able to send enough monies home into their parent countries. Some of these local nationals send these monies back home to either support relatives especially in terms of education as well as making investments and building businesses back home which they can return home to if need be or in case they retire, thus the effect will be tangible in all of these areas. More so, there are some endogenous or internal effects of the pandemic on the African soil. The first effect of the pandemic is the reduction of oil and commodity prices (Tralac, 2020) which are major elements for foreign exchange. Africa is blessed with many natural resources like crude oil which is found in countries Nigeria, Algeria, Angola, Lybia and Egypt amongst others which are mostly exported to foreign countries for foreign exchange. Thus the current state of the global economy which has adversely impacted oil and commodity prices will affect the rate of foreign exchange inflows into the continent from that perspective. Other resources like gold, diamond, cocoa, bauxite, timber, cashew, rubber and many other natural resources gotten from the continent by foreign companies will most likely have reduced demand coupled with reduced prices.

\section{Conclusion}

The continent of Africa has been affected by the pandemic in many ways due to both internal and external factors. However, the continent can brace itself to withstand the effect of such similar global phenomenon by initiating breakwater policies through the establishment of strong intra-regional integration among member countries such as the African Continental Free Trade Area (AfCFTA) in order to foster effective economic bond and interactions among members to strengthen the domestic economy. The continent should also strengthen its ways of economic engagements and interactions by promoting digitalization and e-commerce in order to limit the customary physical human to human eco- 
nomic transactions within its border.

\section{Conflicts of Interest}

The authors declare no conflicts of interest regarding the publication of this paper.

\section{References}

Alfaro, L., \& Chen, M. (2012). Surviving the Global Financial Crisis: Foreign Ownership and Establishment Performance. American Economic Journal: Economic Policy, 4, 30-55. https://doi.org/10.1596/1813-9450-5946

Borga, M., Ibarlucea Flores, P., \& Sztajerowska, M. (2020). Drivers of Divestment Decisions of Multinational Enterprises-A Cross-Country Firm-Level Perspective. OECD Working Papers on International Investment, No. 2019/03, Paris: OECD Publishing. https://doi.org/10.1787/5a376df4-en

Celik, S., Dimertas, G., \& Isaksson, M. (2020). Corporate Bond Market Trends, Emerging Risks, and Monetary Policy. Paris: OECD Capital Market Series.

https://www.oecd.org/corporate/corporate-bond-market-trends-emerging-risks-and-m onetary-policy.htm

Desai, M., Fritz Foley, C., \& Forbes, K. J. (2008). Financial Constraints and Growth: Multinational and Local Firm Responses to Currency Depreciation. Review of Financial Studies, 21, 2857-2888. https://doi.org/10.1093/rfs/hhm017

FAS (2013). International Agricultural Trade Reports: Agricultural Imports Soar in Sub-Saharan Africa.

FAS (2015). International Agricultural Trade Reports: A Turning Point for Agricultural Exports to Sub-Saharan Africa.

Tralac (2020). Impact of the Coronavirus (COVID-19) on the African Economy.

UNCTAD (2020). World Investment Report.

World Bank (2020). Foreign Direct Investment, Net Inflows (BoP, Current US\$) Sub-Saharan Africa.

Worldometers (2020). World/ Countries/ UNITED STATES.

http://www.worldomters.info/coronavirus/country/us

Yang, Y. et al. (2020). The Deadly Coronaviruses: The 2003 SARS Pandemic and the 2020 Novel Coronavirus Epidemic in China. Journal of Autoimmunity, 109, Article ID: 102434. https://doi.org/10.1016/j.jaut.2020.102434 